\title{
Karakteristik Sifat Fisiko-Kimia dan Fungsional Pati Sagu Ihur (Metroxylon sylvestre) Dimodifikasi dengan Hidrolisis Asam
}

\author{
Physico-chemical and Functional Properties of Ihur Sago (Metroxylon sylvestre) Starch by Modified Acid \\ Hydrolysis
}

\author{
Febby Jeanry Polnaya*, Alfredo Andelson Huwae, Gilian Tetelepta \\ Jurusan Teknologi Hasil Pertanian, Fakultas Pertanian, Universitas Pattimura \\ Jl. Ir. M. Putuhena, Kampus Poka, Ambon 97233, Indonesia \\ *Email: febbyjpolnaya@yahoo.com
}

Submisi: 22 November 2016; Penerimaan: 28 November 2017

\begin{abstract}
ABSTRAK
Penelitian ini bertujuan untuk mengkarakteristik pati sagu ihur alami (PSIA) yang dimodifikasi dengan perlakuan hidrolisis asam. Rancangan yang digunakan yaitu rancangan acak lengkap non-faktorial dengan empat taraf perlakuan yaitu PSIA, hidrolisis asam (PSIHA) menggunakan $\mathrm{HCl} 1,1 \mathrm{~N}, 2,2 \mathrm{~N}$, atau 3,3 N. Parameter yang diukur meliputi karakteristik fisik antara lain warna, kemampuan menggelembung, daya larut, kejernihan pasta, dan sifat amilografi. Karakteristik kimia meliputi kadar air, kadar abu, dan amilosa sedangkan karakteristik fungsional yaitu kadar pati resistan (RS). Hasil penelitian menunjukan bahwa perlakuan hidrolisis asam menyebabkan perubahan terhadap sifat fisik warna pati dimana nilai kecerahan $\left(L^{*}\right)$ pati hidrolisis asam $(80,93-81,89)$ lebih tinggi dibandingkan PSIA $(80,29)$. Sebaliknya nilai kemerahan $\left(a^{*}\right)$ dan kekuningan $\left(b^{*}\right)$ PSIHA $(5,13-6,34$ dan $13,21-$ $15,39)$ lebih rendah dibandingkan PSIA $(8,62$ dan 18,24). Perlakuan asam juga menyebabkan kemampuan menggelembung PSIHA (43,88-50,65\%) mengalami penurunan dibandingkan PSIA, tetapi meningkatkan daya larut $(8,92-12,34 \%)$ dan kejernihan pasta $(74,70-77,73 \% 7)$. Untuk sifat kimia, kadar air pati sagu hidrolisis asam $(8,72-$ $15,01 \%)$ dan kadar abu $(0,22-0,37 \%)$ relatif lebih tinggi dibandingkan pati alaminya, namun perlakuan asam menurunkan kadar amilosa (18,29-27,22\%) dan kadar RS (0,06-0,37\%). PSIHA memiliki kestabilan yang lebih baik selama pemanasan dengan breakdown viscosity yang lebih kecil dibandingkan dengan PSIA, serta kecenderungan teretrogradasi lebih rendah, yaitu ditunjukkan nilai setback viscosity yang rendah, dan lebih mudah mengalami gelatinisasi.
\end{abstract}

Kata kunci: Hidrolisis asam; sifat fungsional; sagu ihur; sifat fisiko-kimia; resistant starch

\section{ABSTRACT}

The objective of this study was to characterize modified Ihur sago starch as affected by treatment of acid hydrolysis. A completely randomized experimental non-factorial design was used in this research with four levels of treatments, i.e. native ihur sago starch, $\mathrm{HCl}$ concentrations of $1.1 \mathrm{~N}, 2.2 \mathrm{~N}$, or $3.3 \mathrm{~N}$, subsequently. Physical properties such as color, swelling power, solubility, and paste clarity were measured in this research. Moisture, ash, and amylose content were determined as chemical properties, while the resistant starch (RS) content was determined for its functional properties. Results showed that starch treated with acid hydrolysis caused changes to physical properties in comparison with native starch. These included higher (80.93-81.89) degree of whiteness $\left(L^{*}\right)$ than native starch (80.29), lower redness $\left(a^{*}\right)$ and yellowness $\left(b^{*}\right)$ than native (8.26 and 18.24) having the value of 5.13-6.34, and 13.21-15.39, respectively. Acid hydrolysis not only caused a decrease in swelling power (43.88-50.56\%), but also an increase in solubility $(8.92-12.34 \%)$ and paste clarity $(74.70-77.73 \% \mathrm{~T})$ compared to native starch. Higher moisture and ash content having the value of $8.72-15.01 \%$ and $0.22-0.37 \%$, correspondingly but lower amylose (18.29-27.22\%) and RS content were obtained by acid hydrolysis starch in contrast to native starch. The modified starch has improved heat stability with smaller breakdown viscosity, and setback viscosity less than native starch, and is easily to gelatinize.

Keywords: Acid hydrolysis; functional property; ihur sago; physico-chemical properties; resistant starch 


\section{PENDAHULUAN}

Sagu ihur (Metroxylon sy/vestre) merupakan sumber pati yang potensial baik digunakan sebagai bahan pangan fungsional. Sagu ihur secara genetik memiliki warna kemerahan dibandingkan jenis sagu lain yang berwarna putih, hal ini disebabkan oleh adanya senyawa fenolik pada sagu ihur (Purwani dkk., 2006; Picauly dkk., 2017). Pengolahan pati sagu ihur alami (PSIA) akan meningkatkan nilai ekonomis pati tersebut. Salah satu cara untuk meningkatkan kegunaan dan nilai tambah pati adalah dengan melakukan modifikasi pati agar diperoleh sifat-sifat yang cocok untuk diaplikasi pada industri (Koswara, 2006), seperti dekstrin sebagai penyalut proses enkapsulasi. Salah satu jenis modifikasi yang umum digunakan adalah modifikasi hidrolisis asam.

Hidrolisis asam dihasilkan dengan menghidrolisis pati dengan asam di bawah suhu gelatinisasi, pada suhu kurang dari $35^{\circ} \mathrm{C}$ (Aparicio-Saguilan dkk., 2005). Proses hidrolisis asam terjadi dalam dua tahap penyerangan pada granula pati, yaitu tahap penyerangan secara cepat pada bagian amorf dan tahap penyerangan yang lebih lambat pada bagian kristalin pada fraksi amilopektin (Wurzburg, 1989). Beberapa penelitian yang telah dilakukan menunjukkan bahwa pati dengan perlakuan hidrolisis asam klorida akan menghasilkan pemutusan pada rantai amilosa, sehingga menyebabkan lepasnya molekul-molekul yang lebih kecil yang terlarut dalam air dan terlalu pendek untuk membentuk kompleks dengan iod. Selain itu hidrolisis menyebabkan pemutusan rantai amilosa menjadi gula sederhana, seperti dekstrin (Kusnandar, 2010). Pati hasil hidrolisis asam memiliki sifat-sifat seperti kekentalan yang stabil baik pada suhu tinggi maupun rendah, mempunyai ketahanan terhadap perlakuan mekanis, serta daya pengental yang tahan terhadap kondisi asam dan suhu tinggi sehingga cocok diterapkan dalam skala industri (Koswara, 2006).

Selain mempengaruhi sifat fisiko-kimia pati, hidrolisis asam diharapkan dapat meningkatkan sifat fungsional yaitu kadar pati resistennya (resistant starch, RS). RS merupakan fraksi pati yang tidak dapat dicerna oleh enzim-enzim dalam usus halus, baik akibat proses pengolahan maupun akibat struktur alaminya dalam bahan pangan sehingga mempunyai efek fisiologis yang bermanfaat bagi kesehatan seperti pencegahan kanker kolon, mempunyai efek hipoglikemik (menurunkan kadar gula darah setelah makan), dan hipokolesterolemik (Sajilata dkk., 2006).

RS tipe 3 merupakan pati resisten yang paling penting karena terbentuk terutama akibat proses pengolahan pangan (Kim dkk., 2003). Jumlah RS yang tinggi sangat diperlukan mengingat perannya terhadap kesehatan. Beberapa penelitian menunjukkan bahwa kadar RS dapat ditingkatkan dengan cara modifikasi hidrolisis asam (Aparicio-Saguillan dkk., 2005; Lehmann dkk., 2003; Vasanthan dan Bhatty, 1998). Hidrolisis asam dengan menggunakan asam klorida pada beberapa jenis pati telah dilakukan antara lain pada pati garut (Farida dkk., 2013), pati ubi (Falade dan Ayetigbo,
2015), pati pisang (Aparicio-Saguilan dkk., 2005), dan pati kacang polong (Lehmann dkk., 2003).

Penelitian-penelitian sebelumnya tentang pati sagu ihur belum menunjukkan sifat-sifat fungsionalnya, untuk pati alami ataupun hidrolisis asam, sehingga dalam penelitian ini dilakukan penelitian dengan tujuan untuk mengkarakteristik sifat-sifat fisiko-kimia dan fungsional pati sagu ihur alami (PSIA) dan yang dimodifikasi dengan hidrolisis asam (PSIHA) dengan tiga konsentrasi $\mathrm{HCl}$ yang berbeda.

\section{METODE PENELITIAN}

\section{Bahan}

Bahan yang digunakan dalam penelitian ini adalah PSI, yang merupakan hasil ekstraksi petani lokal di Negeri Alang, Kabupaten Maluku Tengah. PSI hasil ekstraksi petani dibersihkan di laboratorium, dengan cara pencucian berulang-ulang dengan menggunakan air bersih. Pati sagu kemudian disimpan di dalam wadah plastik high-density polyethylene (HDPE) sampai dengan saat digunakan untuk dimodifikasi ataupun dianalisis.

Bahan kimia yang digunakan untuk analisis PSIHA berasal dari Merck, meliputi $\mathrm{HCl}, \mathrm{NaOH}$, asam asetat, etanol, aseton, asam dinitrosalisilat (DNS). Enzim yang digunakan untuk analisis kadar RS meliputi a-amilase (Megazyme, USA) dan enzim amiloglukosidase (Megazyme, USA), sedangkan glukosa oksidase FS berasal dari Diagnostic System International (Holzhein, Jerman).

\section{Modifikasi Hidrolisis Asam Pati Sagu}

Modifikasi hidrolisis asam PSI menggunakan metode yang dikemukakan oleh Aparicio-Saguilan dkk. (2005). Hidrolisis pati menggunakan $\mathrm{HCl}$ dengan konsentrasi asam 1,1 N, 2,2 N, atau 3,3 N. Proses modifikasi asam dengan cara yaitu pada PSI ditambahkan larutan $\mathrm{HCl}$ sesuai perlakuan dengan perbandingan $1: 1(\mathrm{~b} / \mathrm{v})$, kemudian dilakukan proses inkubasi selama 2 jam pada suhu $35^{\circ} \mathrm{C}$. Setelah selesai proses inkubasi maka dilakukan penetralan dengan menggunakan $\mathrm{NaOH}$ hingga mencapai $\mathrm{pH}$ 6, kemudian dilakukan pengendapan selama 1 jam untuk memisahkan residu pati dari supernatan. Setelah selesai pengendapan, supernatan dibuang untuk mendapatkan endapan residu pati, setelah itu dilakukan proses pencucian dengan akuades sebanyak lima kali kemudian dilakukan proses pengeringan selama 8 jam pada suhu $50{ }^{\circ} \mathrm{C}$ untuk menghasilkan PSIHA.

\section{Pengujian Sifat Fisiko-kimia dan Fungsional}

\section{Analisis kadar air}

Analisis kadar air mengacu pada AOAC (1984). Sebanyak $1 \mathrm{~g}$ sampel pati dimasukkan dalam botol timbang yang telah diketahui beratnya. Sampel dipanaskan dalam oven (Memmert, Jerman) pada suhu 
$105{ }^{\circ} \mathrm{C}$ sampai didapat berat tetap. Kadar air sampel didasarkan pada perbedaan berat sampel sebelum dan sesudah dikeringkan.

\section{Analisis kadar abu}

Analisis kadar abu mengacu pada AOAC (1984). Sebanyak $5 \mathrm{~g}$ sampel pati dimasukkan dalam cawan porselin yang telah dikeringkan dan diketahui beratnya. Sampel dibakar dengan pemanas listrik sampai sampel tidak berasap dan diabukan pada tanur pengabuan (Vulcan A-550 Ney, AS) pada suhu $650{ }^{\circ} \mathrm{C}$ sampai dihasikan abu yang berwarna putih keabu-abuan dan beratnya telah konstan. Kadar abu sampel ditentukan dengan menimbang sisa mineral hasil pembakaran bahan organik.

\section{Analisis kadar amilosa}

Analisis kadar amilosa pati mengacu pada AOAC (1984). Sebanyak $100 \mathrm{mg}$ sampel pati ditempatkan ke dalam tabung reaksi $50 \mathrm{~mL}$. Setelah itu ditambahkan 1 $\mathrm{mL}$ etanol $95 \%$ dan $9 \mathrm{~mL} \mathrm{NaOH} 1 \mathrm{M}$ lalu di-vortex. Campuran dipanaskan dalam penangas air mendidih selama 10 menit, kemudian diencerkan hingga $100 \mathrm{~mL}$. Sebanyak $5 \mathrm{~mL}$ larutan sampel dimasukkan ke dalam labu takar $100 \mathrm{~mL}$ dan ditambahkan dengan $1 \mathrm{~mL}$ larutan asam asetat $1 \mathrm{~N}$ dan $2 \mathrm{~mL}$ larutan iod 0,01 N, dan akuades sampai batas tera. Larutan dipanaskan dengan penangas air pada suhu $30^{\circ} \mathrm{C}$ selama 20 menit. Intensitas warna biru yang terbentuk diukur absorbansinya dengan spektrofotometer UV-Vis (Genesys $10 \mathrm{~S}$, Cina) pada $\lambda 620 \mathrm{~nm}$. Absorbansi yang diperoleh diplotkan pada kurva standar dan kadar amilosa dihitung berdasarkan hubungan absorbansi sampel dengan kurva standar.

\section{Analisis warna}

Analisis warna dilakukan dengan menggunakan Chromameter CR 300 Minolta (Jepang). Uji dilakukan dengan sistem warna Hunter $L^{*}, a^{*}, b^{*}$. Chromameter terlebih dahulu dikalibrasi dengan standar warna putih yang terdapat pada alat tersebut.

\section{Analisis kemampuan menggelembung dan daya larut pati}

Analisis kemampuan menggelembung dan daya larut pati mengacu pada metode yang dikemukakan oleh Adebowale dkk. (2009). Pati disuspensi dengan akuades $1 \%$ (b/v) dalam tabung reaksi yang telah diketahui beratnya $\left(W_{1}\right)$. Kemudian dipanaskan pada penangas air (Memmert, Jerman) pada suhu $95^{\circ} \mathrm{C}$ selama 30 menit, lalu didinginkan hingga suhu kamar $\left(27^{\circ} \mathrm{C}\right)$. Selanjutnya suspensi pati dipisahkan dengan alat sentrifugasi (Hermle, Jerman) pada 5000 rpm selama 15 menit, sehingga terpisah residu dan supernatan. Residu hasil sentrifugasi kemudian ditimbang $\left(W_{2}\right)$. Kemampuan menggelembung pati (berdasarkan berat kering) ditentukan seperti pada Persamaan 1.

Kemampuan menggelembung $(\mathrm{g} / \mathrm{g})=\frac{\mathrm{W}_{2}-\mathrm{W}_{1}}{\text { berat pati }}$

Alikuot $(10 \mathrm{~mL})$ dari supernatan dikeringkan hingga berat konstan pada suhu $110^{\circ} \mathrm{C}$. Residu yang terdapat setelah dikeringkannya supernatan, menunjukkan jumlah pati yang terlarut dalam air (\%).

\section{Analisis kejernihan pasta}

Analisis kejernihan pasta pati mengacu pada metode yang dikemukakan oleh Waliszewski dkk. (2003). Suspensi pati dibuat dengan konsentrasi 2\% (b/v) dipanaskan pada penangas air (Memmert, Jerman) dengan suhu $90{ }^{\circ} \mathrm{C}$ selama 30 menit sambil digojog. Suspensi didinginkan hingga suhu $\pm 30^{\circ} \mathrm{C}$, kemudian disimpan pada suhu $4{ }^{\circ} \mathrm{C}$ selama 96 jam dan setiap 24 jam dilakukan pengukuran kejernihan pasta didasarkan nilai transmitansi (\%T). Transmitansi diukur dengan spektrofotometer UV-Vis (Genesys $10 \mathrm{~S}$, Cina) pada $\lambda 650 \mathrm{~nm}$, sebagai blanko digunakan akuades.

\section{Analisis sifat amilografi}

Profil amilografi pati ditentukan menggunakan Rapid Visco Analyser (RVA) (Model RVA-4SA, Newport Scientific Pty Ltd. Warriewood, Australia). Sampel pati $(3 \mathrm{~g})$ didispersikan dalam akuades $(25 \mathrm{~mL})$ dan diaduk dalam RVA canister pada 960 rpm selama 10 detik, dan kemudian diatur kecepatannya $160 \mathrm{rpm}$ sampai dengan akhir pengujian. Pengukuran dilakukan dalam kurun waktu 13 menit. Suhu dan waktu yang digunakan adalah $50{ }^{\circ} \mathrm{C}$ selama 1 menit kemudian dinaikkan suhunya mencapai $95^{\circ} \mathrm{C}$ dalam waktu 3 menit 45 detik kemudain dipertahankan suhunya $95{ }^{\circ} \mathrm{C}$ selama 2 menit 30 detik dan dilanjutkan dengan pendinginan menjadi $50{ }^{\circ} \mathrm{C}$ dalam waktu 3 menit 45 detik, kemudian dipertahankan pada suhu $50{ }^{\circ} \mathrm{C}$ selama 2 menit. Interval antara viskositas dan suhu adalah 4 detik (195 titik data per kurva RVA). Nilai yang terukur dari profil pasta adalah suhu awal gelatinisasi (SAG), peak viscosity (PV), trough viscosity (TV) (minimum viscosity setelah dipertahankan pada suhu $95^{\circ} \mathrm{C}$ ), final viscosity (FV) (viskositas setelah dipertahankan pada suhu $\left.50^{\circ} \mathrm{C}\right)$, breakdown viscosity (BV) (PV - TV), dan setback viscosity (SV) (FV - TV).

\section{Analisis total fenolik}

Analisis total fenolik mengacu pada metode yang dikemukakan oleh Rodriguez-Carpena dkk. (2011). Pati sebanyak $0,5 \mathrm{~g}$ diekstrak dalam $5 \mathrm{~mL}$ pelarut methanol. Selanjutnya diambil ekstrak sebanyak $\pm 0,2 \mathrm{~mL}$ dan ditambahkan $1 \mathrm{~mL}$ reagen folinciocalteu (Merck, Jerman) (pengenceran 1:10, v/v). Kemudian ditambahkan 0,8 $\mathrm{mL}$ sodium karbonat 7,5\% (b/v) 
(Merck, Jerman), selanjutnya dihomogenisasi. Ekstrak dibiarkan di ruang gelap selama 30 menit dan diukur absorbansinya pada $\lambda 725 \mathrm{~nm}$.

\section{Analisis kadar pati resisten}

Analisis kadar pati resisten mengacu pada metode AOAC (2007). Sampel sebanyak $1 \mathrm{~g}$ disuspensikan dalam $50 \mathrm{~mL}$ larutan buffer fosfat 0,08 M, pH 5,5. Kemudian diinkubasi pada suhu $100{ }^{\circ} \mathrm{C}$ sampai tergelatinisasi. Sampel didinginkan pada suhu kamar $\left(27^{\circ} \mathrm{C}\right)$ sampai suhu larutan mencapai $65{ }^{\circ} \mathrm{C}$. Setelah itu, sampel ditambah dengan $10 \mu \mathrm{L}$ enzim a-amilase (Megazyme, AS) dan diinkubasi pada suhu $65{ }^{\circ} \mathrm{C}$ selama 30 menit. Setelah diinkubasi, suspensi ditambahkan $\mathrm{HCl} 1 \mathrm{~N}$ (Merck, Jerman), sampai tercapai pH 4,5. Pada $\mathrm{pH}$ tersebut, ditambahkan $20 \mu \mathrm{L}$ campuran enzim amiloglukosidase (Megazyme, AS) dan diinkubasikan pada suhu $60^{\circ} \mathrm{C}$ selama 60 menit. Sampel diambil $10 \mu \mathrm{L}$ dan ditambah $1 \mathrm{~mL}$ glukosa oksidase FS (Diagnostic System International, Holzhein, Jerman). Sampel diinkubasi selama 20 menit pada suhu $20-25{ }^{\circ} \mathrm{C}$. Peneraan dilakukan dengan menggunakan spektrofotometer UV-Vis (Genesys $10 \mathrm{~S}$, Cina) pada $\lambda$ $500 \mathrm{~nm}$. Kadar RS (\%) dihitung berdasarkan formula seperti pada Persamaan 2.

$\%$ RS $=\frac{1-G \times 0,9}{\text { berat sampel }} \times 100 \%$

Dimana: G merupakan berat glukosa (g); 0,9 adalah faktor konversi $(162 / 180)$ dari D-glukosa bebas yang ditentukan sebagai D-glukosa pada pati.

\section{Rancangan Percobaan}

Penelitian menggunakan rancangan acak lengkap non-faktorial dengan tiga kali ulangan. Data dianalisis menggunakan software SAS 9.1 dan dilanjutkan dengan uji Tukey pada taraf kepercayaan 95\% (a=0,05) untuk mengetahui perbedaan diantara taraf perlakuan.

\section{HASIL DAN PEMBAHASAN}

\section{Warna Pati}

Hasil penelitian menunjukkan bahwa nilai $L^{*}, a^{*}$, dan $b^{*}$ untuk PSIA berturut-turut adalah sebesar 80,29; 8,62; dan 18,24 (Gambar 1), berbeda jika dibandingkan dengan penelitian Polnaya dkk. (2009) yaitu 64,67; 5,62 ; dan 1,87 . Hal ini dapat disebabkan oleh perbedaan sumber PSIA atau proses pengolahan pati. Hasil ini relatif sama yang penelitian Picauly dkk. (2017) yang menunjukkan nilai $L^{*}, a^{*}$, dan $b^{*}$ berturut-turut adalah 80,76; 8,62; dan 17,91.

Warna PSI yang kemerahan dapat disebabkan oleh reaksi pencoklatan yang dikatalisis oleh polifenoloksidase. Reaksi tersebut berlangsung apabila sel mengalami pengrusakan sehingga indigenous fenolik teroksidasi dan menghasilkan warna kecoklatan (Mayer,
1986). Seperti juga yang dikemukakan oleh Purwani dkk. (2006) dan Picauly dkk. (2017), bahwa warna kemerahan dari pati sagu ihur ditentukan oleh senyawa fenolik.

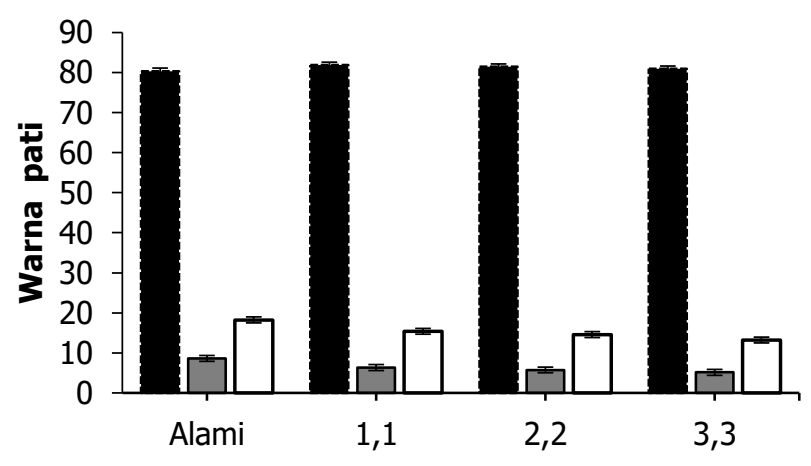

Hidrolisis menggunakan $\mathrm{HCl}(\mathrm{N})$

a Kecerahan $\left(\mathrm{L}^{*}\right) \quad \square$ Kemerahan $\left(\mathrm{a}^{*}\right)$

Gambar 1. Karakteristik sifat warna pati sagu ihur alami dan hidrolisis asam

Nilai kecerahan $\left(L^{*}\right)$ pati hidrolisis asam $(80,93-$ $81,89)$ lebih tinggi dibandingkan PSIA $(80,29)$. Sedangkan pada kadar kemerahan $\left(a^{*}\right)$ dan kekuningan $\left(b^{*}\right)$ pati PSIHA $(5,13-6,34$ dan $13,21-$ 15,39) lebih rendah dibandingkan PSIA $(8,62$ dan $18,24)$. Nilai $L^{*}, a^{*}$ dan $b^{*}$ PSIA relatif sama dengan penelitian Picauly dkk. (2017). Meningkatnya nilai $L^{*}$ dapat disebabkan oleh peranan ion klorida $\left(\mathrm{Cl}^{-}\right)$. Ion klorida dihasilkan oleh reaksi antara satu pasang elektron bebas pada atom oksigen dengan ion hidrogen dari $\mathrm{HCl}$, menghasilkan ion hidronium dan ion klorida (Utomo, 2008). Ion klorida yang terbentuk merupakan anion yang reaktif dan mempunyai kemampuan sebagai pemutih, sehingga ketika PSIA dihidrolisis menggunakan $\mathrm{HCl}$ menyebabkan kenaikan nilai $L^{*}$ atau meningkatkan kecerahannya.

Tabel 1. Karakteristik sifat-sifat fisiko-kimia pati sagu ihur alami dan hidrolisis asam

\begin{tabular}{ccc}
\hline Perlakuan & $\begin{array}{c}\text { Kemampuan } \\
\text { menggelembung } \\
(\mathrm{g} / \mathrm{g})\end{array}$ & Daya larut (\%) \\
\hline $\mathrm{PSIA}$ & $50,65 \pm 0,01^{\mathrm{a}}$ & $7,41 \pm 0,34^{\mathrm{b}}$ \\
$\mathrm{HCl} 1,1 \mathrm{~N}$ & $48,43 \pm 0,02^{\mathrm{ab}}$ & $8,50 \pm 0,13^{\mathrm{b}}$ \\
$\mathrm{HCl} 2,2 \mathrm{~N}$ & $46,79 \pm 0,02^{\mathrm{ab}}$ & $10,57 \pm 0,38^{\mathrm{ab}}$ \\
$\mathrm{HCl} 3,3 \mathrm{~N}$ & $43,88 \pm 0,02^{\mathrm{b}}$ & $12,34 \pm 0,47^{\mathrm{a}}$ \\
\hline
\end{tabular}

Keterangan: PSIA = pati sagu ihur alami; ${ }^{a b}$ nilai yang diikuti dengan huruf yang sama pada kolom yang sama menunjukkan tidak ada perbedaan nyata berdasarkan uji Tukey pada taraf $a=$ 0,05 .

\section{Kemampuan Menggelembung dan Daya Larut Pati}

Hasil penelitian menunjukkan bahwa kemampuan menggelembung PSIA sebesar 50,65 g/g. Hasil yang relatif sama ditunjukkan oleh Picauly dkk. (2017) yaitu sebesar 50,73\%, tetapi lebih rendah jika dibandingkan 
dengan penelitian Polnaya dkk. (2009) yaitu sebesar $77,78 \mathrm{~g} / \mathrm{g}$. Perbedaan ini mungkin saja disebabkan oleh perbedaan sumber PSIA yang digunakan dalam penelitian ini.

Kemampuan menggelembung PSIHA (43,88-48,43 $\mathrm{g} / \mathrm{g}$ ) lebih rendah dibandingkan PSIA (Tabel 1). Hal ini disebabkan oleh perlakuan hidrolisis asam meningkatkan derajat hidrolisis pati dan menghasilkan molekul yang berukuran kecil dan mudah larut air. Hasil yang relatif sama juga dikemukakan oleh Sandhu dkk. (2007).

Sun dkk. (2015) mengemukakan bahwa selama perlakuan asam, ikatan hidrogen antara polimer pati yang berdekatan terganggu dan terjadi pengikisan pada daerah amorf dan menyebabkan rendahnya kemampuan menggelembung, sedangkan Palma-Rodriguez dkk. (2012) menyatakan bahwa pada pati terhidrolisis asam dimana amilosa luruh dan rantai pendek amilopektin meningkat akan membentuk struktur lebih bercabang tetapi kemampuan menggelembung menurun. Di lain pihak, dengan pendeknya rantai pati sifat kristalinitas pati meningkat sehingga kemampuan menggelembung menurun. Hal ini disebabkan penggelembungan dihambat oleh kekokohan dari jaringan amilosa pada daerah kristalin pati. Menurut Radhika dan Moorthy (2008), kelarutan pati dipengaruhi oleh kemampuan menggelembung, kekuatan asosiasi dan adanya komponen lainnya seperti lipid.

Hasil penelitian menunjukkan bahwa daya larut PSIA adalah sebesar 7,41\%. Hasil yang relatif sama ditunjukkan oleh Picauly dkk. (2017) yaitu sebesar $4,86 \%$, tetapi lebih rendah jika dibandingkan dengan penelitian Polnaya dkk. (2009) yaitu sebesar 77,78 g/g. Perbedaan ini mungkin saja disebabkan oleh perbedaan sumber PSIA yang digunakan dalam penelitian ini.

Daya larut PSIHA (8,50\%-12,34\%) lebih tinggi dibandingkan PSIA (7,41\%). Hal ini disebabkan oleh PSIHA lebih mudah terlarut dibandingkan pati alaminya. Meningkatnya daya larut pati dapat disebabkan oleh rantai pati yang lebih pendek dihasilkan selama hidrolisis dan hal ini juga berhubungan dengan melemahnya ikatan hidrogen. Pratiwi dkk. (2015) mengemukakan bahwa granula pati dengan berat molekul amilosa yang rendah lebih mudah terlarut dan keluar dari granula, ke dalam medium sekitarnya.

Omojola dkk. (2010) mengemukakan bahwa asam akan menyerang daerah amorf maupun kristalin dari granula pati sehingga menghasilkan molekul yang mudah larut dalam air. Selain itu, Osunsami dkk. (1989) mengemukakan bahwa hidrolisis asam menyebabkan memendeknya rantai polimer pati sebagai akibat melemahnya ikatan hidrogen. Menurut Singh (2004), melemahnya ikatan hidrogen di dalam pati memudahkan air untuk masuk ke dalam granula pati sehingga meningkatkan kelarutan pati. Proses hidrolisis telah merusak granula dan memecah rantai pati menjadi lebih pendek sehingga lebih mudah terlarut. Rantai pati yang lebih pendek menunjukkan berat molekul yang lebih kecil sehingga meningkatkan daya larut.

\section{Kejernihan Pasta Pati}

Kejernihan pasta PSIHA berkisar antara 74,70$77,73 \% T$ pada jam ke-0 pengukuran, lebih tinggi dibandingkan PSIA yaitu 58,3\% T. Kecenderungan yang sama juga ditunjukkan pada pengukuran jam ke24, 72, dan 96 (Gambar 2). Rendahnya kejernihan pasta pati alami berhubungan dengan lebih mudahnya pengaturan kembali molekul liniear amilosa melalui ikatan hidrogen yang menyebabkan meningkatnya absorpsi cahaya pada saat pengukuran kejernihan. Gonçalves dkk. (2014) mengemukakan bahwa tingginya persentasi $T$ pati hidrolisis asam juga berhubungan dengan rendahnya kadar amilosa pati asam. Kejernihan pasta dapat dijelaskan tidak hanya oleh jumlah amilosa, tetapi juga oleh rantai kecil dari molekul ini, karakteristik yang menunjukan keselarasan lebih mudah dari rantai linier (Karam dkk., 2005).

Persen trasmitansi gel pati menurun seiring dengan meningkatnya waktu penyimpanan pati yang disimpan pada suhu $4{ }^{\circ} \mathrm{C}$ (Gambar 2). Hal ini disebabkan oleh apabila pasta pati dibiarkan mendingin, lama kelamaan akan menjadi buram karena proses retrogradasi dan akan dipercepat pada suhu rendah sehingga menyebabkan kejernihan pasta menjadi menurun. Karam dkk. (2005) mengemukakan bahwa setelah penyimpanan 72 jam sampel menjadi lebih keruh. Hal ini disebabkan oleh stabilitas rendah dari amilosa dalam larutan, menyebabkan asosiasi rantai linear melalui ikatan hidrogen.

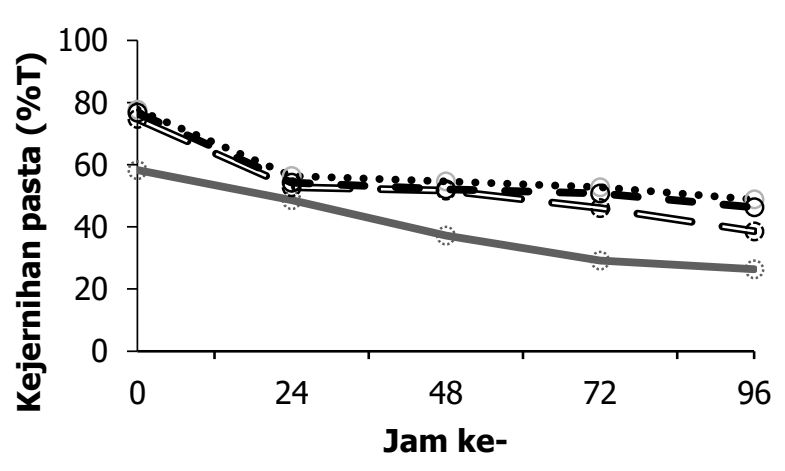

alami $\cdots . \cdot 1,1 \mathrm{~N}-\mathrm{O}-2,2 \mathrm{~N} \Leftrightarrow \cdot 3,3 \mathrm{~N}$

Gambar 2. Pengaruh hidrolisis asam terhadap kejernihan pasta pati sagu ihur

Hasil yang sama juga ditunjukkan oleh beberapa peneliti yang menganalisis pati dari berbagai sumber botani setelah disimpan kurang lebih 4 hari (Gonçalves dkk., 2014; Izidoro dkk., 2007; Picauly, dkk. 2017; Yamani, 2010). Takizawa dkk. (2004) mengemukakan bahwa daya larut pati berhubungan dengan kejernihan pasta. Semakin tinggi daya larut pati maka semakin tinggi juga kejernihan pasta pati. Hal ini juga sama dengan hasil penelitian ini, disebabkan oleh molekul pati terhidrolisis asam menunjukkan daya larut yang tinggi dan meningkatnya transparansi. 


\section{Karakteristik Amilografi Pati}

Karakteristik amilografi PSIA dan PSIHA ditunjukkan pada Tabel 2. Perlakuan hidrolisis asam menggunakan $\mathrm{HCl}$ sesuai perlakuan menyebabkan terjadinya perubahan sifat pati. Viskositas pasta PSIHA cenderung menurun seiring meningkatkan konsentras $\mathrm{HCl}$ yang digunakan selama hidrolisis asam. Suhu awal gelatinisasi (SAG) PSIA sebesar $73,95{ }^{\circ} \mathrm{C}$ lebih tinggi dari PSIHA perlakuan $\mathrm{HCl} 1,1 \mathrm{~N}\left(73,65{ }^{\circ} \mathrm{C}\right)$, tetapi lebih rendah dibandingkan perlakuan $\mathrm{HCl} \quad 2,2 \mathrm{~N}\left(74,36{ }^{\circ} \mathrm{C}\right)$, sedangkan untuk perlakuan konsentrasi $\mathrm{HCl} 3,3 \mathrm{~N}$ tidak terdeteksi. Charles dkk. (2005) mengemukakan bahwa tingginya SAG PSIA dipengaruhi oleh kandungan amilosanya, yang membentuk formasi kristalin. Menurunnya SAG pati sebagai akibat hidrolisis asam merupakan konsekuensi melemahnya ikatan-ikatan hidrogen granula pati dan disintegrasi selama proses modifikasi, sehingga pati lebih mudah tergelatinisasi. Hidrolisis diduga akan menurunkan stabilitas struktur dari pati dengan menghambat ikatan heliks ganda seperti ikatan hidrogen sehingga menurunkan perpindahan energi panas pada saat gelatinisasi.

Viskositas puncak (VP) PSIA yaitu sebesar $5.816 \mathrm{cP}$ lebih tinggi dibandingkan PSIHA (77-960 CP). Meningkatnya konsentrasi $\mathrm{HCl}$, menyebabkan rendahnya puncak viskositas pasta. Hasil yang sama juga ditunjukkan oleh Fouladi dan Nafchi (2014) dan Sandhu dkk. (2007). Hal ini disebabkan oleh rusaknya daerah amorf sehingga membentuknya rantai-ratani pendek selama hidrolisis. Babu dkk. (2015) menyatakan bahwa rendahnya VP pati modifikasi asam akibat pemutusan rantai pada daerah amorf dan produksi dekstrin dengan berat molekul rendah. Fouladi dan Nafchi (2014) mengemukakan bahwa hidrolisis asam efektif menurunkan VP pati sagu. Menurunnya VP disebabkan oleh terbentuknya rantai-rantai pendek selama proses hidrolisis (Sandhu dkk., 2007).

Trought viscosity (viskositas pasta panas, TV) menunjukkan nilai viskositas setelah dipertahankan selama 5 menit pada suhu $95{ }^{\circ} \mathrm{C}$. PSIA menunjukkan sifat TV lebih tinggi (1779 cP) dibanding perlakuan PSIHA (39-247 CP) (Tabel 2). Semakin tinggi konsentrasi $\mathrm{HCl}$, nilai TV pati semakin menurun. Hasil yang sama juga ditunjukkan oleh Babu dkk. (2015) untuk pati ubi jalar hidrolisis asam sitrat, nilai TV-nya cenderung menurun. Menurunnya TV mengindikasikan bahwa pati hasil hidrolisis semakin stabil selama pemanasan.

Breakdown viscosity (penurunan viskositas selama pemanasan, BV) menunjukkan kestabilan pasta selama pemanasan. Nilai BV pati sagu alami sebesar 4037 cP, lebih tinggi dibanding perlakuan pati sagu hidrolisis asam (38-703 CP) (Tabel 2). Semakin tinggi konsentrasi $\mathrm{HCl}$, BV semakin rendah, hal ini menunjukkan bahwa pasta PSIHA yang terbentuk akan semakin stabil terhadap panas dan pengadukan. Hasil yang sama juga ditunjukkan oleh Sandhu dkk. (2007), yang menyatakan bahwa modifikasi asam dengan $\mathrm{HCl}$ akan menurunkan nilai BV pati.

Final viscosity (viskositas akhir, FV) menunjukkan nilai viskositas setelah didinginkan hingga suhu $50^{\circ} \mathrm{C}$. Nilai FV PSIA sebesar $3.070 \mathrm{CP}$ lebih tinggi dibandingkan perlakuan PSIHA (342-717 cP) (Tabel 2). Semakin tinggi konsentrasi $\mathrm{HCl}$, FV PSIHA semakin rendah. Hasil yang sama juga telah dilaporakan oleh Babu dkk. (2015) bahwa hidrolisis asam menyebabkan lisis pada ikatan glikosidik dari rantai amilopektin panjang yang menyebabkan rendahnya viskositas akhir.

Setback viscosity (SV) menunjukkan viskositas selama proses pendinginan. Nilai SV PSIA sebesar $1.291 \mathrm{CP}$, lebih tinggi dibandingkan PSIHA (342-717 CP). Meningkatnya konsentrasi $\mathrm{HCl}$, menyebabkan SV PSIHA semakin rendah. Hal ini menunjukkan bahwa kecenderungan PSIHA untuk mengalami retrogradasi sangat rendah. Rendahnya SV PSIHA diduga disebabkan oleh sifat newtonian dari gel pati itu sendiri dan karena kurangnya waktu dari molekul pati untuk berikatan kembali selama pengukuran viskositas (Thirathumthavorn dan Charoenrein, 2005).

Peak time (PT) menunjukkan waktu puncak pada saat pati tergelatinisasi maksimal (mencapai puncak viskositas). Hasil penelitian menunjukkan bahwa PSIA membutuhkan waktu yang lama untuk mencapai PV yaitu 6,73 menit dibandingkan PSIHA (5,87-6,13 menit). Hasil yang sama juga ditunjukkan oleh Babu dkk. (2015) yang menghidrolisis pati ubi jalar dengan

Tabel 2. Karakteristik sifat-sifat amilografi pati sagu ihur alami dan hidrolisis asam

\begin{tabular}{cccccccc}
\hline Perlakuan & SAG $\left({ }^{\circ} \mathrm{C}\right)$ & PV (cP) & TV (cP) & BV (cP) & FV (cP) & SV (cP) & $\begin{array}{c}\text { Peak time } \\
(\mathrm{min})\end{array}$ \\
\hline Pati alami & $73,95 \pm 0,56^{\mathrm{a}}$ & $5816 \pm 5,65^{\mathrm{a}}$ & $1778,50 \pm 4,95^{\mathrm{a}}$ & $4037,50 \pm 0,71^{\mathrm{a}}$ & $3070 \pm 7,07^{\mathrm{a}}$ & $1291,50 \pm 2,12^{\mathrm{a}}$ & $6,72 \pm 0,02^{\mathrm{a}}$ \\
$\mathrm{HCl} \mathrm{1,1} \mathrm{N}$ & $73,65 \pm 0,71^{\mathrm{a}}$ & $960 \pm 7,07^{\mathrm{b}}$ & $247 \pm 8,48^{\mathrm{b}}$ & $713 \pm 1,41^{\mathrm{b}}$ & $717,50 \pm 4,94^{\mathrm{b}}$ & $470,50 \pm 3,53^{\mathrm{b}}$ & $5,88 \pm 0,03^{\mathrm{c}}$ \\
$\mathrm{HCl} 2,2 \mathrm{~N}$ & $74,36 \pm 0,28^{\mathrm{a}}$ & $481 \pm 4,24^{\mathrm{c}}$ & $80,50 \pm 4,94^{\mathrm{c}}$ & $400,50 \pm 0,70^{\mathrm{c}}$ & $519,50 \pm 6,36^{\mathrm{c}}$ & $439 \pm 1,41^{\mathrm{c}}$ & $5,93 \pm 0,04^{\mathrm{c}}$ \\
$\mathrm{HCl} \mathrm{3,3} \mathrm{N}$ & $\mathrm{tt}^{\mathrm{b}}$ & $77 \pm 2,83^{\mathrm{d}}$ & $38,50 \pm 3,53^{\mathrm{d}}$ & $38,50 \pm 0,71^{\mathrm{d}}$ & $343 \pm 4,24^{\mathrm{d}}$ & $304,50 \pm 0,70^{\mathrm{d}}$ & $6,12 \pm 0,01^{\mathrm{b}}$ \\
\hline
\end{tabular}

Keterangan: SAG = suhu awal gelatinisasi; PV = peak viscosity (viskositas puncak); TV = trought viscosity (viskositas pasta panas); BV = breakdown viscosity, FV = final viscosity (viskositas akhir); $\mathrm{SV}=$ setback viscosity, $\mathrm{tt}=$ tidak terdeteksi ${ }^{\mathrm{ab}}$ nilai yang diikuti dengan huruf yang sama pada kolom yang sama menunjukkan tidak ada perbedaan nyata berdasarkan uji Tukey pada taraf $a=0,05$. 
asam sitrat. Hal ini menunjukkan bahwa PSIHA lebih mudah mengalami gelatinisasi dibandingkan pati alaminya, disebabkan oleh menurunnya kestabilan strukturnya.

\section{Kadar Air}

Kadar air PSIA yaitu sebesar $11,60 \%$, relatif sama dengan penelitian Picauly dkk. (2017) yaitu 11,57\%, tetapi lebih rendah jika dibandingkan dengan penelitian Polnaya dkk. (2009) yaitu sebesar $12,53 \%$ maupun Purwani (2006) sebesar 17,03\%. Hal ini dapat disebabkan oleh perbedaan sumber PSIA atau proses pengolahan pati.

Kadar air PSIHA $(8,72-15,01 \%)$ relatif lebih tinggi dibandingkan PSIA (Tabel 3). Penelitian Babu dkk. (2015) tentang hidrolisis asam menggunakan asam sitrat juga menunjukkan hasil yang relatif sama, yaitu terjadi peningkatan kadar air setelah pati terhidrolisis. AparicioSaguilan dkk. (2005) menyebutkan bahwa lebih tingginya kadar air pati terhidrolisis asam disebabkan proses hidrolisis asam menghasilkan rantai-rantai linear yang memiliki daya ikat air lebih tinggi.

\section{Kadar Abu}

Kadar abu PSIA yaitu sebesar $0,06 \%$, relatif sama dengan penelitian Picauly dkk. (2017) yaitu 0,05\%, lebih rendah jika dibandingkan dengan penelitian Purwani (2006) sebesar 0,26\%. Hal ini dapat disebabkan oleh perbedaan sumber PSIA, proses pengolahan pati atau metode analisis.

Rendahnya kadar abu PSIA disebabkan oleh pencucian berulang dengan air sebelum digunakan untuk perlakuan. Pencucian tersebut dapat menyebabkan terlarutnya mineral oleh air pencuci sehingga kandungan mineralnya berkurang. Selain itu proses ekstraksi juga dapat menyebabkan hilangnya mineral karena mineral tersebut dapat ikut terbawa ampas.

Kadar abu PSIHA $(0,22-0,37 \%)$ lebih tinggi dibandingkan pati alaminya (Tabel 3). Hasil relatif sama juga ditunjukkan oleh Farida dkk. (2013). Hasil penelitiannya menunjukkan bahwa kadar abu pati garut hasil hidrolisis asam menggunakan $\mathrm{HCl}$ meningkat menjadi $3,69 \%$, dibandingkan pati alaminya yaitu $0,22 \%$. Hal ini disebabkan oleh residu mineral masih terikut dalam proses pengendapan pati. Meningkatnya kadar abu pada pati hidrolisis asam dikarenakan residu mineral akibat proses penetralan asam dengan $\mathrm{NaOH}$.
Mineral yang tersisa merupakan garam $\mathrm{NaCl}$ yang terbentuk saat penetralan $\mathrm{HCl}$ dan $\mathrm{NaOH}$ sehingga terhitung sebagai abu (Farida dkk., 2013).

\section{Kadar Amilosa}

Kadar amilosa PSIA yaitu sebesar 27,22\%, relatif sama dengan penelitian Picauly dkk. (2017) yaitu $27,18 \%$, tetapi lebih rendah jika dibandingkan dengan penelitian Polnaya dkk. (2009) yaitu sebesar 35,13\% dan Purwani dkk. (2006) yaitu sebesar 37,24\%. Hal ini dapat disebabkan oleh perbedaan sumber PSIA, proses pengolahan pati atau metode analisis. Kadar amilosa cenderung menurun dengan meningkatnya kosentrasi asam (Tabel 3). Omojola dkk. (2011) menunjukkan hasil yang relatif sama yaitu kadar amilosa pati cola hidrolisis asam lebih rendah dibandingkan pati alaminya. Aparicio-Saguilan dkk. (2005) mengemukakan bahwa menurunnya kadar amilosa selama hidrolisis asam disebabkan oleh hidrolisis terutama di daerah amorf, dimana amilosa juga berada. Hasil ini sejalan dengan penelitian pada pati jagung (Wang dkk., 2003), pati garut (John dkk., 2002), pati beras, jagung, dan kentang (PalmaRodriguez dkk., 2012). Menurut Wang dkk. (2003), terjadi sedikit peningkatan derajat kristalinitas pati terhidrolisis asam dengan kadar amilosa lebih rendah dibanding pati alaminya yaitu dari $27,5 \%$ menjadi $24,8 \%$ menggunakan $\mathrm{HCl} 1,0 \mathrm{~N}$. Menurut PalmaRodriguez dkk. (2012), perlakuan asam menurunkan kadar amilosa pada semua jenis pati yang diuji dengan nilai antara 3,1 dan 6,4\%.

Rendahnya kadar amilosa PSIHA dapat disebabkan oleh reaksi hidrolisis menyebabkan lepasnya molekulmolekul yang lebih kecil yang terlarut dalam air dan terlalu pendek untuk membentuk kompleks dengan iod. Selain itu hidrolisis menyebabkan pemutusan rantai amilosa menjadi gula sederhana, seperti dekstrin. Menurut Kusnandar (2010), dekstrin merupakan polisakarida yang dihasilkan dari hasil hidrolisis pati (terutama amilosa) yang memiliki struktur linier.

\section{Resistant Starch}

Tingginya RS PSIA $(6,54 \%)$ berhubungan dengan kristalinitas pati dan juga dipengaruhi oleh keberadaan senyawa fenolik yang terdapat pada granula pati. Hasil analisis kadar total fenolik PSIA adalah 7,91\%. Penelitian Picauly dkk. (2017) menunjukkan kadar fenolik yang relatif sama. Picauly dkk. (2017)

Tabel 3. Karakteristik sifat-sifat fisiko-kimia pati sagu ihur alami dan hidrolisis asam

\begin{tabular}{ccccc}
\hline Perlakuan & Kadar air (\%) & Kadar abu (\%) & Amilosa (\%) & Kadar RS (\%) \\
\hline PSIA & $11,60 \pm 0,19^{\mathrm{ab}}$ & $0,06 \pm 0,02^{\mathrm{c}}$ & $27,22 \pm 0,04^{\mathrm{a}}$ & $6,54^{\mathrm{a}}$ \\
HCl 1,1 N & $8,72 \pm 0,14^{\mathrm{b}}$ & $0,22 \pm 0,04^{\mathrm{b}}$ & $22,97 \pm 0,13^{\mathrm{ab}}$ & $6,01^{\mathrm{ab}}$ \\
$\mathrm{HCl} 2,2 \mathrm{~N}$ & $14,82 \pm 0,05^{\mathrm{a}}$ & $0,35 \pm 0,03^{\mathrm{a}}$ & $20,26 \pm 0,38^{\mathrm{b}}$ & $5,07^{\mathrm{ab}}$ \\
$\mathrm{HCl} 3,3 \mathrm{~N}$ & $15,01 \pm 0,10^{\mathrm{a}}$ & $0,37 \pm 0,02^{\mathrm{a}}$ & $18,29 \pm 0,29^{\mathrm{b}}$ & $3,90^{\mathrm{b}}$ \\
\hline
\end{tabular}

Keterangan: PSIA = pati sagu ihur alami; RS = Resistant Starch; ${ }^{\text {ab }}$ nilai yang diikuti dengan huruf yang sama pada kolom yang sama menunjukkan tidak ada perbedaan nyata berdasarkan uji Tukey pada taraf $a=0,05$. 
mengemukakan bahwa senyawa fenolik dapat menghambat aktivitas enzim pencernaan, sehingga bertanggung jawab terhadap resistensi PSIA terhadap agen penyebab degradasi.

Kadar RS PSIHA (3,90-6,01\%) lebih rendah dibandingkan pati alaminya (Tabel 3). Hasil yang relatif sama juga ditunjukkan oleh Pratiwi dkk. (2015) kadar RS PSIHA mengalami penurunan setelah hidrolisis dibandingkan pati alaminya. Hal ini dapat disebabkan oleh hidrolisis pati menyebabkan rusaknya struktur amilopektin dan menghasilkan rantai linear yang pendek sehingga meningkatkan mobilitas molekul. Beberapa hasil penelitian (Aparicio-Saguillan dkk., 2005; Lehmann dkk., 2003; Vasanthan dan Bhatty, 1998) menunjukkan bahwa terjadi peningkatan kadar RS setelah dimodifikasi dengan cara hidrolisis asam, setelah dimodifikasi lanjut dengan berbagai jenis modifikasi lainnya.

Menurunnya kadar RS pati hidrolisis asam mungkin disebabkan oleh hidrolisat dibentuk oleh polimer kurang dari 10 satuan glukosa. Hal ini dapat mempengaruhi pembentukan RS yang optimal. Polimer lebih kecil dari 10 satuan glukosa dapat menghambat retrogradasi, yang sangat berpengaruh terhadap kadar RS. Menurut Schmiedl dkk. (2000), panjang rantai yang optimal untuk pembentukan RS tipe 3 adalah a-(1-4)-D-glukan antara dengan DP 10 dan 40. Hasil ini menunjukkan bahwa kadar RS PSIA, relatif tinggi dan sangat dipengaruhi oleh kadar fenoliknya, sedangkan modifikasi hidrolisis asam menyebabkan menurunnya kadar RS.

\section{KESIMPULAN}

Perlakuan hidrolisis asam menggunakan $\mathrm{HCl} 1,1 \mathrm{~N}$, 2,2 $\mathrm{N}$ atau 3,3 N, menghasilkan sifat fisiko-kimia dan fungsional PSIHA berbeda dibandingkan pati alaminya. Perbedaan ditunjukkan pada sifat warna, menurunnya kemampuan menggelembung, tetapi meningkatkan daya larut dan kejernihan pasta. Kadar air, kadar abu PSIHA relatif lebih tinggi dibandingkan pati alaminya sedangkan kadar amilosa lebih rendah. Sifat-sifat amilografi PSIHA lebih redah dibandingkan PSIA. Kadar RS PSIHA lebih rendah dibandingkan pati alaminya. Tingginya kadar RS PSIA lebih dipengaruhi oleh kadar fenoliknya. Walaupun kadar RS-nya rendah, tetapi PSIHA dapat digunakan untuk modifikasi ganda sehingga dapat meningkatkan sifat tersebut.

\section{DAFTAR PUSTAKA}

Adebowale, K.O., Henle, T., Schwarzenbolz, U., \& Doert, T. (2009). Modification and properties of african yam bean (Sphenostylis stenocarpa Hochst. Ex A. Rich.) Harms starch I: Heat moisture treatments and annealing. Food Hydrocolloids, 23(7), 19471957.https://doi.org/10.1016/j.foodhyd.2009.01.002.

[AOAC] Association of Official Analytical Chemists. 1984. Official Methods of Analysis of The Association of Official Analytical Chemists. $14^{\text {th }}$ ed. AOAC Inc. Arlington, Virginia.

[AOAC] Association of Official Analytical Chemists. 2007. Official Methods of Analysis of The Association of Official
Analytical Chemists, $18^{\text {th }}$ edn. Washington DC.

Aparicio-Saguilán, A., Flores-Huicochea, E., Tovar, J., Gracíasuárez, F., Gutiérrez-Meraz, F., \& Bello-Pérez, L.A. (2005). Resistant starch-rich powders prepared by autoclaving of native and lintnerized banana starch: partial characterization. Starch/Stärke, 57(9), 405-412. https://doi.org/10.1002/star.200400386.

Babu, A.S., Parimalavalli, R., \& Rudra, S.G. (2015). Effect of citric acid concentration and hydrolysis time on physicochemical properties of sweet potato starches. International Journal of Biological Macromolecules, 80, 557-565. https://doi.org/10.1016/j.ijbiomac.2015.07.020.

Charles, A.L., Chang, Y.H., Ko, W.C., Sriroth, K., \& Huang, T.C. (2005). Influence of amylopectin structure and amylose content on the gelling properties of five cultivars of cassava starches. Journal of Agricultural and Food Chemistry, 53(7), 2717-2725. https://doi.org/10.1021/jf048376+.

Falade, K.O. \& Ayetigbo, A.E. (2015). Effects of annealing, acid hydrolysis \& citric acid modifications on physical and functional properties of starches from four yam (Dioscorea spp.) cultivars. Food Hydrocolloids, 43, 529539. https://doi.org/10.1016/j.foodhyd.2014.07.008.

Farida, D.N., Rahayu, W.P., \& Apriyadi, M.S. (2013). Modifikasi pati garut (Marantha arundinacea) dengan perlakuan hidrolisis asam dan siklus pemanasanpendinginan untuk menghasilkan pati resisten tipe 3 . Jurnal Teknologi Industri Pertanian, 23(1), 61-69.

Fouladi, E. \& Nafchi, A.M. (2014). Effects of acid-hydrolysis and hydroxypropylation on functional properties of sago starch. International Journal of Biological Macromolecules, 68 , https://doi.org/10.1016/j.ijbiomac.2014.05.013.

Gonçalves, P.M., Noreña, C.P.Z., da Silveira, N.P., \& Brandelli, A. (2014). Characterization of starch nanoparticles obtained from Araucaria angustifolia seeds by acid hydrolysis and ultrasound. $\angle W T$ - Food Science and Technology, 58(1), 21-27. https://doi.org/10.1016/j.lwt.2014.03.015.

John, J.K., Raja, K.C.M., Rani, S., Moorthy, S.N., \& Eliasson, A. (2002). Properties of arrowroot starch treated with aqueous $\mathrm{HCl}$ at ambient temperature. Journal of Food Science, 67(1), 10-14. https://doi.org/10.1111/j.13652621.2002.tb11350.x.

Karam, L.B., Grossmann, M.V.E., Silva, R.S.S.F., Ferrero, C., \& Zaritzky, N.E. (2005). Gel textural characteristics of corn, cassava and yam starch blends: a mixture surface response methodology approach. Starch/Starke, 57(2), 62-70. https://doi.org/10.1002/star.200400328.

Kim, S.K., Kwak, J.E., \& Kim, W.K. (2003). A simple method for estimation of enzyme-resistant starch content. Starch/Stärke, 55(8), 366-368. https://doi.org/10.1002/star.200300199.

Kusnandar, F. (2010). Kimia Pangan Komponen Makro. Jakarta (ID): PT. Dian Rakyat.

Lehmann, U., Rossler, C., Schmiedl, D., \& Jacobasch, G. (2003). Production and physicochemical characterization of resistant starch type III derived from pea starch. Nahrung, 47(1), 60-63. https://doi.org/10.1002/food.200390014.

Mayer, A.M. (1986). Polyphenol oxidases in plants-recent progress. Phytochemistry, 26(1), 11-20. https://doi.org/10.1016/S0031-9422(00)81472-7.

Omojola, M.O., Akinkunmi, Y.O., Olufunsho, KO., Egharevba, H.O., \& Martins, E.O. (2010). Isolation and 
physicochemical characterization of cola starch. African Journal Food Agriculture Nutrition Development, 10(7), 2884-2900.

Osunsami, A.T, Akingbala, J.O., \& Oguntimein, G.B. (1989). Effect of storage on starch content and modification of cassava starch. Starch/Starke, 41(2), 54-57. https://doi.org/10.1002/star.19890410205.

Palma-Rodrigues, H.M., Agama, A.E., Mendez, M.G., Gonzalez, S.R.A., Vernon, C.E., \& Bello, P.L.A. (2012). Effect of acid treatment on the physicochemical and structural characteristics of starches from different botanical sources. Starch/Starke, 64, 115-125. https://doi.org/10.1002/star.201100081.

Picauly, P., Damamain, E., \& Polnaya, F.J. (2017). Karakteristik fisiko-kimia dan fungsional pati sagu ihur termodifikasi dengan heat moisture treatment. Jurnal Teknologi dan Industri Pangan, 28(1), 70-77. http://dx.doi.org/10.6066/jtip.2017.28.1.70.

Polnaya, F.J., Talahatu, J., Haryadi, \& Marseno, D.W. (2009). Karakterisasi tiga jenis pati sagu (Metroxylon sp.) hidroksipropil. Agritech, 29(2), 87-95.

Pratiwi, W.S.W., Anal, A.K., \& Putra S.R. (2015). Production by lintnerization-autoclaving and physicochemical characterization of resistant starch 3 from sago palm (Metroxylon sagu Rottb). Indonesian Journal of Chemistry, 15(3), 295-304.

Purwani, E.Y., Widaningrum, Thahir, R., \& Muslich. (2006). Effect of heat moisture treatment of sago starch on its noodle quality. Indonesian Journal of Agricultural Science, 入1), 8-14.

Rodríguez-Carpena, J.G., Morcuende, D., Andrade, M.J., Kylli, P., \& Estévez, M. 2011. Avocado (Persea americana Mill.) phenolics, in vitro antioxidant and antimicrobial activities, and inhibition of lipid and protein oxidation in porcine patties. Journal of Agricultural and Food Chemistry, 59(10), 5625-5635. http://doi.org/10.1021/jf1048832.

Sajilata, M.G., Singhal, R.S., \& Kulkarni, P.R. (2006). Resistant starch - a review. Comprehensive Reviews in Food Science and Food Safety, 5(1), 1-17. https://doi.org/10.1111/j.1541-4337.2006.tb00076.x.

Sandhu, K.S., Singh, N., \& Lim, S.T. (2007). A comparison of native and acid thinned normal and waxy corn starches; physicochemical, thermal, morphological and pasting properties. LWT - Food Science and Technology, 40(9), 1527-1536. https://doi.org/10.1016/j.Iwt.2006.12.012.

Schmiedl, D., Bäuerlein, M., Bengs, H., \& Jacobasch, G. (2000). Production of heat-stable, butyrogenic resistant starch. Carbohydrate Polymers, 43(2), 183-193. https://doi.org/10.1016/S0144-8617(00)00147-8.

Singh, N., Chawla., D., \& Singh, J. (2004). Influence of acetic anhydride on physicochemical, morphological and thermal properties of corn and potato starch. Food Chemistry, 86(4),

$601-$ 608.https://doi.org/10.1016/j.foodchem.2003.10.008.

Sun, Q., Zhu, X., Si, F., \& Xiong, L. (2015). Effect of acid hydrolysis combined with heat moisture treatment on structure and physicochemical properties of corn starch. Journal of Food Science and Technology, 52(1), 375-382. http://doi.org/10.1007/s13197-013-0998-7.

Takizawa, F.F., Silva, G.O., Konkel, F.E., \& Demiate, I.M. (2004). Characterization of tropical starches modified with potassium permanganate and lactic acid. Brazilian Archives of Biology and Technology, 476), 921-931. http://dx.doi.org/10.1590/S1516-89132004000600012.
Utomo, M.P. (2008). Teori Asam-Basa. Makalah Pengabdian Pada Masyarakat. Universitas Negeri Yogyakarta.

Waliszewski, K.N., Aparicio, M.A., Bello, L.A., \& Monroy, J.A. (2003). Changes of banana starch by chemical and physical modification. Carbohydrate Polymer, 52(3), 237242. https://doi.org/10.1016/S0144-8617(02)00270-9.

Wang, Y.J., Truong, V.D., \& Wang, L.F. (2003). Structures and rheological properties of corn starch as affected by acid hydrolysis. Carbohydrat Polymer, 52(3), 327-333. https://doi.org/10.1016/S0144-8617(02)00323-5.

Wurzburg, O.B. (1989). Modified Starches: Properties and Uses. Boca Raton: CRC Press.

Yamani, B.V. (2010). Physico-chemical and functional characterization of tuber starches originating in South America: Oca (Oxalis tuberosa Molina), Alluco (Ullucus tuberosus Caldas) and Mashua (Tropaeolum tuberosum Ruiz e Pavón). Dissertation. São Paulo: Universidade de São Paulo. 